DOI 10.4467/25439561KSR.18.013.9371

JAN NoWAK (D) https://orcid.org/0000-0001-6880-3748

Kuria Metropolitalna w Krakowie

Wicepostulator Procesu Beatyfikacyjnego

ks. Władysława Bukowińskiego

\title{
ŻYCIE I HEROIZM \\ KS. WŁADYSŁAWA BUKOWIŃSKIEGO \\ W KAZACHSTANIE
}

\author{
THE LIFE AND HEROISM \\ OF FATHER WŁADYSŁAW BUKOWIŃSKI \\ IN KAZAKHSTAN
}

\section{Streszczenie}

Ks. Władysław Bukowiński żył w latach 1904-1974. Dobrowolnie poświęcił się zesłańcom - katolikom w Karagandzie. Studia prawnicze i teologiczne odbył na Uniwersytecie Jagiellońskim w Krakowie. Jako kapłan pracował w diecezji krakowskiej i w Łucku. Za wierność Bogu, Kościołowi i Ojczyźnie spędził ponad 13 lat w więzieniach i obozach pracy Związku Radzieckiego. Po uwolnieniu służył przez 20 lat zesłańcom w Kazachstanie.

Heroizm życia ks. Bukowińskiego ma swe źródło w decyzji pozostania na stałe wśród zesłańców w Kazachstanie, z pełną świadomością wszelkich konsekwencji tej decyzji. Wierność Bogu i człowiekowi oparł na heroicznych, ludzkich i ewangelicznych, wartościach i cnotach. Podstawą człowieczeństwa były dla niego cnoty kardynalne, na których budują wiara, nadzieja i miłość. Wierzył, że Bóg go potrzebuje wśród zesłańców i ufał Bogu mimo okrucieństwa ludzi, poniżających jego godność i bliźnich. Miłość Boga sprawiła, że ją zachował i nie dał się zatruć nienawiścią.

Ks. Bukowiński to człowiek, dla którego pokora, ubóstwo, posłuszeństwo i czystość są dobrą nowiną o tym, jaką wartość ma prawda dla tego, kto nią żyje. Nie ulega wattpliwości, że dla ks. Władysława, który je wypełniał w stopniu heroicznym, były drogą do świętości. Dlatego 11 września 2016 został beatyfikowany w Karagandzie. 


\begin{abstract}
Father Władysław Bukowiński (1904-1974) voluntarily devoted himself to the exiles - Catholics in Karaganda. He studied law and theology at the Jagiellonian University in Krakow. As a priest he worked in the diocese of Kraków and Lutsk. He spent over 13 years in prisons and labor camps of the Soviet Union due to his allegiance to God, the Church and his fatherland,. After being released, he served the exiles in Kazakhstan for 20 years.

Bukowiński's heroism of life has its source in the decision to remain among the exiles in Kazakhstan, despite his full awareness of all the consequences of this decision. He based his fidelity to God and man on the heroic human and evangelical values and virtues. For him, the cardinal virtues on which faith, hope and love are built were the basis of humanity. He believed that his presence among the exiles is God's will and he trusted Him despite the cruelty of people who humiliated his and his fellow men's dignity. God's love was the cause that he kept it and did not let it be poisoned by hatred.

Bukowiński is a man for whom humility, poverty, obedience and purity are the good news about the value of truth for those who live according to that truth. There is no doubt that they were the way to holiness for Fr. Władysław, who fulfilled them in a heroic degree. On the 11 September 2016, he was beatified in Karaganda.
\end{abstract}

Słowa kluczowe: Heroizm, zesłaniec, cnoty, prawda, zaufanie Keywords: Heroism, exile, virtues, truth, trust

\title{
1. Krótka historia życia ks. Władysława Bukowińskiego
}

Ks. Władysław Bukowiński urodził się 22 grudnia 1904 roku w Berdyczowie. Jego ojciec, JózefCyprian, pochodził z rodziny ziemiańskiej a jego matka Jadwiga Scipio del Campo pochodziła ze spolszczonej rodziny włoskiej. Zmarła w 1918 roku w Płoskirowie na Podolu. Władysław Bukowiński w latach 1912-1913 mieszkał w Opatowie w okolicach Sandomierza. W 1914 roku rozpoczął naukę w rosyjskim gimnazjum w Kijowie, następnie uczył się w Żmerynce, a od 1917 roku w polskim gimnazjum w Płoskirowie. W roku 1920, uchodząc przed bolszewicką inwazją, kilkunastoletni Władysław przeprowadził się wraz z rodziną do Polski. Odbywał eksternistyczne kursy i w 1921 roku zdał maturę w Krakowie, a następnie rozpoczął studia prawnicze na Uniwersytecie Jagiellońskim. W tym samym czasie, tj. w latach 1923-1925 studiował i ukończył z wyróżnieniem Polską Szkołę Nauk Politycznych przy Wydziale Prawa Uniwersytetu Jagiellońskiego. Działał w Akademickim Kole Kresowym skupiającym studentów przybyłych z Kresów Wschodnich. Studia prawnicze ukończył 24 czerwca 1926 roku, otrzymując tytuł magistra prawa z możliwością pisania pracy doktorskiej. W tym samym roku wstąpił do seminarium duchownego 
i rozpoczął studia teologiczne na Uniwersytecie Jagiellońskim. Przygotowanie do kapłaństwa obejmowało zarówno zdobywanie wiedzy teologicznej, jak i formację duchową przyszłego kapłana. Święcenia kapłańskie otrzymał w katedrze krakowskiej na Wawelu 28 czerwca $1931 \mathrm{r}$.

Od 1 września 1931 roku do 20 czerwca 1935 roku pracował jako katecheta w gimnazjum w Rabce. Przez kolejny rok był wikariuszem i katechetą w szkole powszechnej w Suchej Beskidzkiej'.

\subsection{Kresy - miejsce służby i cierpienia}

Ks. Władysław Bukowiński w 1936 roku na własną prośbę wyjechał na Kresy Wschodnie. Wykładał katechetykę i socjologię w seminarium duchownym w Łucku. W roku 1938 został sekretarzem Diecezjalnego Instytutu Akcji Katolickiej i równocześnie redaktorem czasopisma Akcji Katolickiej „Spójnia” oraz dyrektorem Wyższego Instytutu Wiedzy Religijnej i zastępcą redaktora „Życia Katolickiego”. Od 1939 roku był proboszczem katedry w Łucku. Dzielił się wówczas z potrzebującymi wszystkim, co miał. 22 sierpnia 1940 roku został uwięziony przez NKWD. Przebywał w łuckim więzieniu do 26 czerwca 1941 roku. Cudem uniknął śmierci w czasie masowego rozstrzeliwania więźniów przed wkroczeniem Niemców. Po uwolnieniu nadal był proboszczem katedry.

W nocy z 3 na 4 stycznia 1945 roku został aresztowany i oskarżony o zdradę władzy radzieckiej na rzecz Watykanu, a za nielegalną działalność duszpasterską skazany zaocznie na 10 lat karnych obozów pracy. Od 1946 roku ks. Władysław przebywał w czelabińskim obozie, a w 1950 przewieziony został do obozu pracy w kopalni miedzi w Dżezkazganie. Po wyczerpującej, kilkunastogodzinnej pracy odwiedzał chorych w więziennym szpitalu, umacniał współwięźniów w wierze i nadziei, udzielał sakramentów, prowadził rekolekcje w różnych językach. Swoją codzienną Eucharystię przeżywał szczególnie: sprawował ją bardzo wcześnie rano, gdy jeszcze wszyscy spali, klęcząc na pryczy, która była zarazem ołtarzem, w więziennych łachmanach zamiast ornatu. Nie skarżył się na tych, którzy go skazali czy też źle traktowali. By podnieść ducha patriotyzmu wśród Polaków, napisał i wykładał historię Polski pod tytułem Historia nauczycielka życia.

${ }^{1}$ Por. Stuga Boży ks. Władystaw Bukowiński (1904-1974). Materiały z sympozjum zorganizowanego w Sanktuarium Bożego Miłosierdzia w Krakowie-Łagiewnikach 23 czerwca 2007 roku w pierwszą rocznicę rozpoczęcia procesu kanonizacyjnego, red. J. Nowak, Kraków, Wydawnictwo UNUM, 2007, s. 44. 


\subsection{Karaganda i droga bohaterskiego zesłańca}

10 sierpnia 1954 roku ks. Władysław został zwolniony z obozu i zesłany do Karagandy, gdzie natychmiast podjął tajne duszpasterstwo wśród Polaków Niemców. Był pierwszym księdzem katolickim, który przybył do Karagandy. Jako zesłaniec miał obowiązek meldować się co miesiąc na komisariacie i zdawać dokładne relacje, gdzie przebywał i co robił. Nazywał te meldunki „,comiesięczną spowiedzią”. W czerwcu 1955 roku odrzucił propozycję powrotu do Polski. Aby zostać na stałe w Kazachstanie, gdzie widział potrzebę apostolstwa, zdecydował się przyjąć obywatelstwo ZSRR. Miał pełną świadomość wszelkich konsekwencji tej decyzji, ale pozostał wierny swojemu powołaniu². W czerwcu 1957 roku wyjechał w okolice Ałma-Aty do polskich przesiedleńców, gdzie od 20 lat nie było kapłana. Poza tym był jeszcze w Aktiubińsku i Semipałatyńsku.

W 1958 roku Bukowiński został aresztowany i uwięziony za działalność religijną. Na rozprawie 25 lutego 1959 roku oskarżony o nielegalne utworzenie kościoła, agitację dzieci i młodzieży oraz posiadanie literatury antyradzieckiej zrezygnował z obrońcy i wykorzystując swoje prawnicze wykształcenie, sam wygłosił mowę. Otrzymał najniższy z możliwych wymiar kary: trzy lata obozu pracy. Ks. Bukowiński spędził w więzieniach i obozach pracy 13 lat 5 miesięcy i 10 dni.

W 1965 roku ks. Bukowiński otrzymał pozwolenie na pierwszy wyjazd w odwiedziny do krewnych w kraju. 3 czerwca 1965 roku, po blisko trzydziestu latach nieobecności, przyjechał do Polski. Spotykał się z rodziną, dawnymi przyjaciółmi, ale nie chciał pozostać, gdyż czuł się bardziej potrzebny w Karagandzie. Do Polski przyjechał jeszcze w 1969 roku i w grudniu 1972. Spotykał się z kardynałem Karolem Wojtyłą, który żywo interesował się sytuacją w Kazachstanie. W grudniu 1967 roku odbył czwartą misję w Tadżykistanie. Ten okres pracy w Kazachstanie wyróżniała posługa szafarza Bożego Miłosierdzia. Ze względu na zły stan zdrowia była to ostatnia podróż apostolska... Wyczerpany pracą i długotrwałą chorobą zmarł w Karagandzie 3 grudnia 1974 roku. Życie ks. Władysława można zawrzeć w słowach: HEROIZM MIŁOSIERDZIA.

\section{2. „Heroizm cnót - wiara, nadzieja, miłość”}

Niezwykłe życie ks. Bukowińskiego miało źródło w kapłaństwie i całkowitym oddaniu się działalności duszpasterskiej. Jego postawa bycia dla zesłańców i spraw-

\footnotetext{
${ }^{2}$ Zob. W. Bukowiński, Wybór wspomnień i informacji dla moich przyjaciót, oprac. ks. J. Nowak, Kraków, Wydawnictwo Instytutu Teologicznego Księży Misjonarzy, 2007, s. 22-24.
} 
ności duchowe, dojrzewające w ekstremalnych sytuacjach były bohaterskie. Dotknijmy więc jego bogactwa wewnętrznego, życiem potwierdzonych cnót, przez co najlepiej widać jego heroizm. Nie sposób w krótkim wykładzie omówić ten temat wyczerpująco, ale konieczna jest chociażby krótka refleksja nad każdą z cnót.

\subsection{Wiara w stopniu heroicznym}

Ks. Władysław był obdarzony przez Boga wieloma darami, które wykorzystał i rozwiną pracą wewnętrzną. Owocem tego współdziałania były sprawności, cnoty osiagnięte w stopniu heroicznym. Na pierwszy plan w jego życiu i pismach wysuwają się wiara i nadzieja, których owocem jest miłość.

Siłą jego wiary budował się Jan Paweł II, który napisał list do uczestników sympozjum w Karagandzie, zwołanego z okazji setnej rocznicy urodzin i trzydziestej rocznicy śmierci ks. W. Bukowińskiego:

„Bogu dziękuję, że mogłem go osobiście poznać, budować się jego świadectwem i wspierać w każdy możliwy w tamtych czasach sposób. Nigdy oprócz modlitwy nie prosił o nic dla siebie, ale zawsze był otwarty na wszystko, co mogło dać oparcie w wierze i w cierpieniu tym, których Pan Bóg powierzył jego pieczy. Podziwiałem jego oddanie i duszpasterski zapał. Niestraszne mu były przeciwności, a nawet więzienie, byle tylko uciśniony Lud Boży mógł czerpać z jego posługi”’3.

O bogactwo wiary troszczył się przede wszystkim dla swoich wiernych w Karagandzie i w czasie krótkich wypraw misyjnych. Każda spowiedź, katecheza, kazanie służyły jednemu tylko celowi: uświadomieniu ludziom, że Opatrzność Boża zawsze się o nas troszczy, warto Jej całkowicie zaufać i przyjąć wolę Bożą, choćbyśmy uważali, że jej udźwignięcie jest ponad nasze siły. Jakże wymowna jest w tym kontekście jego uwaga:

„Opatrzność Boża działa i przez ateistów, posłali mnie tam, gdzie ksiądz był potrzebny"4.

Mimo szeroko prowadzonej przez komunistów walki ideologicznej, ks. Bukowiński nie poddawał się. Wykorzystywał różne sytuacje, aby dzielić się swoim bogactwem wiary - w czasie potajemnych spotkań w domach katolików, ale też w trakcie swych podróży misyjnych, kiedy koleją przemierzał tysiące kilometrów. Jedną $\mathrm{z}$ takich rozmów $\mathrm{w}$ przedziale wagonu przeprowadził $\mathrm{z}$ Rosjaninem, studentem

\footnotetext{
${ }^{3}$ Archiwum ks. kard. F. Macharskiego.

${ }^{4}$ W. Bukowiński, Wybór wspomnień..., op.cit., s. 22
} 
ostatniego kursu uniwersytetu w Ałmacie, typowym radzieckim agnostykiem, nie tyle z przekonania, co z powodu braku możliwości zgłębienia problemów filozoficzno-religijnych. Ks. W. Bukowiński zaznajomił go z chrześcijaństwem i w końcu tak podsumował:

„Żegnając się ze mną, podziękował mi bardzo serdecznie i powiedział jakże bardzo znamienne słowa: 'To właśnie jest to, czego nam brakuje'”'

Ukazywał ludziom, zwłaszcza młodym, czym jest wewnętrzna wolność. Wiedział też, że dzięki tej świadomości wielu z nich uchroni swą wiarę.

Ten apostoł wiary potrafił objąć swym duszpasterstwem całą Karagandę, odbyć kilka podróży misyjnych w latach 1957-1968 i równocześnie przyjmować tych, którzy pokonywali nieraz tysiące kilometrów, by się u niego spowiadać. Wiele uwagi poświęcił listom pisanym do przyjaciół, chorym i cierpiącym. Warto odnotować konkretne uwagi ich autora na temat ufności. W roku 1958, sam przeżywając cierpienia, pisał do chorej adresatki:

„Tam gdzie zawodzi medycyna, pozostaje już tylko ufność w Opatrzność, która nie zawodzi nigdy, o ile jest naprawdę silna i całkowita. A więc ufajmy!”’.

Oprócz prowadzenia indywidualnych formacji, dużo uwagi poświęcał pracy wśród rodzin. Ks. Władysław przychodził do domów mimo zakazów i represji. Ciągle bowiem był nękany przez władzę z powodu pracy duszpasterskiej. Gdyby te prześladowania go zniechęciły i przeraziły, wówczas ludzie nie doświadczyliby pełnej wiary troski, która była potrzebna wielu w tych bolesnych momentach życia. Taka postawa świadczy jak wielkie jest znaczenie heroicznej wiary.

\subsection{Nadzieja}

Wierni bardzo cenili sobie jego optymizm, czerpiąc siły z takiej postawy i sycąc się jego wiarą. Niezwykłe musiało być zaufanie kapłana, skoro już wówczas głosił Miłosierdzie Boże w Kazachstanie, choć nawet w Polsce w tym okresie (lata 60. XX w.) to szczególne nabożeństwo było raczej mało znane. Tymczasem Ludmiła Wierzbicka, mieszkanka Karagandy, wspomina:

„Nam było bardzo ciężko, był głód, a On ciągle mówił, że przyjdą lepsze czasy. Ciaggle mówił, że trzeba się dużo modlić i ufać, że będzie lepiej. W 1973 roku nauczył

${ }^{5}$ Ibidem, s. 53.

${ }^{6}$ Listy. Ks. Władysław Bukowiński, red. ks. J. Nowak, Kraków, Wydawnictwo św. Stanisława BM, 2007, s. 414. 
mnie Koronki do Miłosierdzia Bożego. Podarował mi obrazek Pana Jezusa Miłosiernego. On chyba jako pierwszy do Kazachstanu przywiózł orędzie Miłosierdzia Bożego"?.

Jego zaufanie do Boga czyniło cuda. Ryzykując życiem, sprawował sakramenty, świadom, że może go to kosztować nowe aresztowanie a nawet śmierć. Całą nadzieję pokładał w Bogu. Wspomina Jerzy Węgierski, jeden ze współwięźniów w łagrze:

„W mojej pamięci ks. Bukowiński pozostał jako kapłan w pracy duszpasterskiej niezmiernie gorliwy niezależnie od środowiska i warunków, w jakich się znalazł. Miał nadzwyczaj głęboką wiarę w opatrzność Bożą i w pożyteczność swej pracy duszpasterskiej. Był pełen miłości do Boga i ludzi, chyba ogólnie odczuwano jego świętość. Był przyjazny w stosunku do wszystkich, otwarty i życzliwy, interesujący się innymi; nawet we wrogach widział ludzi”" .

Każdy dom katolików, który otwierał drzwi, był dla niego „kościołem”. Wiedział, że duszpasterstwo rodzin jest szczególnie cenne. Sam starał się zawsze pokładać nadzieję w Bogu. Zarówno poczucie godności, jak i patriotyzm, a zwłaszcza Boże miłosierdzie wobec potrzebujących, ukazywały Bukowińskiemu, jak wielkie jest znaczenie heroicznej nadziei pokładanej w Bogu - bez nich bowiem nie mógłby sprostać wielu zadaniom.

\subsection{Miłość Boga i bliźniego}

Miłość Boża w sercu kapłana pomagała mu także w najtrudniejszych warunkach ciagłych przesłuchań i inwigilacji. Oczywiście cierpiał z tego powodu, ale umiał swój ból ofiarować Bogu. Udowodnił, że miłość Boża prowadzi i ochrania, ale trzeba głosić i katechizować.

Nauczanie katechizmu dostosowywał do możliwości katolików. Wiedział, że gorąco pragnęli Boga, dlatego przygotowywał ich do przyjęcia daru Bożej miłości w spowiedzi i Komunii św. oraz kolejnych sakramentów. Proces ten był nieraz bardzo krótki, trwał zaledwie kilka dni lub godzin:

„Moja katecheza, tak dla dzieci, jak i dla dorosłych przygotowujących się do pierwszej spowiedzi i Komunii świętej, jest podzielona na 6 punktów: 1) Bóg, 2) Jezus Chrystus, 3) Kościół Katolicki, 4) Żywot wieczny, 5) Spowiedź, 6) Komunia święta"”.

\footnotetext{
${ }^{7}$ Archiwum prywatne księdza Jana Nowaka (APKJN).

${ }^{8}$ Stuga Boży ks. Władysław Bukowiński (1904-1974)..., op.cit., s. 25

${ }^{9}$ W. Bukowiński, Wybór wspomnień..., op.cit., s. 91.
} 
Katecheza i głoszone kazania były wyrazem i świadectwem Bożej miłości. Z całą pewnością ks. Władysław był świadomy zagrożenia, płynącego z kontaktu duszpasterskiego z ewentualnymi konfidentami komunistycznymi. W swoim postępowaniu postawił jednak wszystko na jedną kartę, gdyż był pewny, że dzieło, które kontynuuje, jest wyrazem woli Boga i Jego miłości.

Najwyżej w miłości do ludzi ceni przyjaźń, co wyraża w listach do najlepszych przyjaciół. Pełnię serdecznych uczuć zawiera w korespondencji adresowanej do ks. Chomickiego. W ostatnim liście z dnia 13 listopada 1974 roku pisał:

„Kochany Antosiu, najserdeczniejsze braterskie pozdrowienie w Chr. Pozdrawiam i dziękuję, że wciąż jeszcze o mnie pamiętacie...Nie jest wesoło być sługą nieużytecznym. Tem więcej krzepi mię to, co widziałem na Podolu, że jednak są tacy, co są i młodzi i użyteczni... Krótkie, lecz głębokie refleksje ogarnęły mnie na grobie Bronia: On wytrwał aż do śmierci! Dziękuję Ci, Kochany Antosiu, za tak bardzo miłą, a dla mnie zaszczytna, gościnę, Trwajmy w miłości Chrystusowej! Przyjaźni Twojej polecam także i Józia, osamotnionego po śmierci Bronia" ${ }^{\prime 10}$.

W swoich wspomnieniach podsumuje życie ze względu na trud związany z miłością bliźniego:

„Zdaje się, że nie dałem się nigdy zatruć nienawiścią i że miłość nieprzyjaciół nie była samą tylko piękną teorią w mym życiu na wschodzie" ${ }^{11}$.

\section{Cnoty kardynalne}

Cnoty kardynalne są podstawą człowieczeństwa i na nich, jak na glebie, wyrastają wiara, nadzieja i miłość.

\subsection{Roztropność}

Ks. Bukowiński ceni wysoko roztropność. Zachowanie spokoju w więzieniu stawało się wielkim wyzwaniem i świadczyło zarówno o chrześcijańskiej roztropności, jak i wielkiej dojrzałości duchowej. Żadne cierpienie nie było w stanie przekreślić celu, do jakiego dążył kapłan. Po opuszczeniu więzienia skrajnie wyczerpany i wynędzniały, dalej pełnił powierzoną mu posługę proboszcza i nadal aktywnie pomagał uciekinierom, jeńcom, ratował żydowskie dzieci przed śmiercią. Nie rezygnował

\footnotetext{
${ }^{10}$ Listy..., op.cit., s. 34

${ }^{11}$ W. Bukowiński, Wybór wspomnień..., op.cit., s. 72.
} 
z obranej drogi i stawiał posługę kapłańską zawsze na pierwszym miejscu nawet w najtrudniejszych sytuacjach.

Opuszczając Łuck, patrzył z samochodu więziennego na katedrę łucką, świadomy zakończenia pewnego etapu w swoim życiu. Przyjął to wydarzenie jako zrządzenie Opatrzności Bożej i zawierzył jej całkowicie. We wspomnieniach pisał:

„Teraz jedziemy do Kijowa, a potem zapewne jeszcze o wiele dalej na wschód. Tam na Wschodzie jest moja przyszłość życiowa z woli Opatrzności Bożej. Obym godnie wypełnił tą wolę Opatrznościową"12.

Tą przyszłością, jak się okazało, był pobyt w więzieniach i łagrach. Człowiek, który żył w takich warunkach, będąc po ludzku roztropnym, mógł chcieć tylko przetrwać, przetrzymać, nie narażając się nikomu, myśląc wyłącznie o sobie i wykorzystując każdą sytuację, aby ułatwić sobie życie. Ale nie ks. Bukowiński. Kierując się nadprzyrodzoną roztropnością i wiarą w celowość swojego pobytu w obozie pracy, nieustannie szukał sposobności do apostołowania. W Dżezkazganie spotkał także innych kapłanów, z którymi wspólnie organizował pracę duszpasterską. Ojciec Ryszard Czesław Grabski dał świadectwo z przygotowania do chrześcijańskiego przeżycia Wielkanocy:

„Zbliżała się Wielkanoc. Ks. Władysław Bukowiński szukał w myśli sposobów, jak przygotować naszych ziomków do Świąt Wielkanocnych"13.

„Szukanie w myśli sposobów” w realiach obozowych wymagało niezwykłej inteligencji i roztropności. To, co w warunkach normalnych wydawało się proste, w łagrze, gdzie działalność duszpasterska była surowo zabroniona, stawało się czynem niemal bohaterskim. Roztropność dawała mu pokój w sercu i siłę pozostania wiernym i posłusznym w wypełnianiu do końca woli Bożej, co było wówczas heroizmem.

\subsection{Sprawiedliwość}

Jako student i założyciel Akademickiego Koła Kresowego:

,[...] kierował sprawami finansowymi. On jeden chyba orientował się, komu i kiedy Koło spieszyło pomocą. Czynił to tak dyskretnie i taktownie, że nikt z nas nigdy pytań nie zadawał. Mieliśmy bezgraniczne zaufanie do jego rozeznań i decyzji"14.

\footnotetext{
${ }^{12}$ Ibidem, s. 21-22.

${ }^{13}$ J. Nowak, Świadek. Życie i działalność ks. Władysława Bukowińskiego, apostoła Kazachstanu, Kraków, Wydawnictwo UNUM, 2009 s. 75.

${ }^{14}$ Archiwum Naszej Przeszłości, ANP 374, 9.
} 
Sprawiedliwość wyrażała się u Bukowińskiego zwłaszcza w jego gorliwości duszpasterskiej i dbałości o sprawy Boże. Ujawniła się ona w jego życiu szczególnie tam, gdzie została naruszona sprawiedliwość wobec innych. Im większą niesprawiedliwość spotykał, tym więcej wysiłku wkładał w to, aby sprawiedliwość realizować w swoim życiu. Nie bez znaczenia jest fakt, że ponad trzynaście lat, czyli znaczną część swej służby kapłańskiej, spędził w więzieniach oraz obozach pracy. Ks. Eliasz Głowacki - współwięzień ks. Bukowińskiego zaświadczył:

„W tym piekle zła, niesprawiedliwości, krzywdy, bólu i cierpienia szukałem człowieka - wzoru dla siebie. Tym wzorem człowieka i kapłana był dla mnie przez dziewięć lat w łagrach i pozostanie na zawsze ks. Władysław Bukowiński”"15.

Nie omieszkał wymierzyć sprawiedliwość, broniąc słabszych:

„Parę razy byłem jeszcze nie tyle bity, co mocno popchnięty przez współwięźniów żulików, a zresztą $\mathrm{i}$ ja sam z własnej inicjatywy z całą energią przyłożyłem rękę do jednego z żulików, który się znęcał nad pewnym staruszkiem"16.

\subsection{Umiarkowanie}

Umiar i wyrzeczenie widoczne są w pracy i w relacjach z bliźnimi. W pracy duszpasterskiej szedł wszędzie, gdzie go zapraszano. Najczęściej były to małe pomieszczenia, w których z trudem mieścili się wierni. Ciasnota i zaduch nigdy mu nie przeszkadzały i nie narzekał na nie. Naturalny i bezpośredni kontakt kapłana z ludźmi sprawiał, że w czasie spotkań szybko mijało skrępowanie i wszyscy czuli się swobodnie. Ks. Władysław nie domagał się specjalnego traktowania, a nawet nie pozwalał na nie. Nie martwił się o siebie i swoje sprawy. W pismach ks. Bukowińskiego nie ma ani jednego tekstu, który sygnalizowałby u niego brak umiaru. Zmagania z codziennością są dowodem dowartościowania w życiu kapłana tej cnoty. Przyjmował wszystkie niedogodności życia ze spokojem, radością, zachowując przy tym godność. Swoją postawą i podejściem do spraw materialnych umacniał tych, u których przebywał. Nikt w kontakcie z nim nie czuł się skrępowany i upokorzony swoim ubóstwem. Cały dobytek miał w dwóch walizkach. W jednej rzeczy osobiste, w drugiej liturgiczne.

Znamienne jest to, że do końca życia nie utracił pogody ducha i wewnętrznego pokoju. Umiar cechował każdy aspekt jego życia. Potwierdzają to zgodnie wszyscy,

\footnotetext{
${ }^{15}$ J. Nowak, Świadek... op.cit., s. 79.

${ }^{16} \mathrm{~W}$. Bukowiński, Wybór wspomnień..., op.cit., s. 16.
} 
którzy go kiedyś poznali. Nigdy na nic nie narzekał, przyjmując wszystkie trudy, doświadczenia, ograniczenia, a nawet zagrożenie życia jako dar Boży. Udowodnił, że duszpasterstwu nie potrzeba wielkich środków materialnych, aby wypełniać wiernie i skutecznie swoje powołanie. Zdobytą na studiach i przez całe życie pogłębianą wiedzę oddawał w służbie miłości tym, do których był posłany. Był człowiekiem wszechstronnie wykształconym, intelektualistą, a mówił prosto o sprawach trudnych tak, że wszyscy go rozumieli i słuchali - zdumieni jego mądrością. Pogłębiał swoje życie wewnętrzne i wykorzystywał każde, nawet ekstremalne przeżycie, aby na kolejnych etapach swojej drogi lepiej wykonywać swoją pracę.

\subsection{Męstwo}

W 1940 r. w Łucku został zabrany z dworca i uwięziony. Przesłuchanie kapłana podczas śledztwa trwało kilka dni i było także wielką próbą męstwa, której sprostał młody kapłan. Wściekły krzyk oficera, że nie wolno się modlić, ksiądz Bukowiński ze spokojem skwitował słowami:

„Proszę się uspokoić, w przyszłości będę się tak modlił, żeby pan tego nie zauważył" ${ }^{\prime \prime}$.

Zdarzenie to ukazuje, jak bardzo dojrzałym wewnętrznie i odważnym był już wtedy kapłan. Nie bał się, bo znał potęgę ducha, którego nie da się uwięzić. Był mężny mocą Boga. Sam tak komentuje to zdarzenie:

„Przemoc ma także swoje granice. Któż może mi zabronić się modlić. Co najwyżej może się tylko sam ośmieszyć. Modlić się można naprawdę zawsze i wszędzie, byle tylko była dobra wola ku temu. Ciało można zamknąć i nawet całymi latami trzymać w pojedynczej celi więziennej, lecz nie uwięzi się ducha, który i stamtąd znajduje drogę wprost do Boga!"'18

\section{Cnoty ewangeliczne}

Dla ks. Bukowińskiego pokora, ubóstwo, posłuszeństwo i czystość były drogą do świętości. Nie ulega wątpliwości, że kapłan wypełniał je w stopniu heroicznym.

\footnotetext{
${ }^{17}$ Ibidem, S. 19.

${ }^{18}$ Ibidem.
} 


\subsection{Pokora}

Współwięzień księdza, F. Kaszyński, wspomina ciężkie czasy sowieckich łagrów, podkreślając jego niesamowitą pokorę:

„Ile razy wydawano ubranie ks. Władysławowi, jak na pośmiewisko: bluza krótka, rękawy krótkie, spodnie krótkie, wyżej kostek i obuwie zawsze ciasne, szczególnie walonki zimą, zmoknięte oddawane do suszenia, po czym nie można było włożyć na nogi, a mróz bywał -35, nogi okropnie cierpiały. Ks. Władysława nigdy nie widziałem zasmuconego lub utyskującego na swoje położenie, w jakim się znalazł, zawsze z jaśniejącym, uśmiechniętym obliczem chodził"'19.

Bukowiński nie zniechęcał się, co potwierdził w napisanych później wspomnieniach:

„Wciąż nie jestem rejestrowany, wciąż nie mam uznania 'de iure'. Jest jednak teraz swego rodzaju uznanie „de facto”, co się wyraża też w pobieraniu ode mnie podatku dochodowego. Urzędnicy finansiści objaśniali mi, że zarejestrowany ksiądz, pracujący w zarejestrowanym kościele, płaci podatek tak jakby kościół był fabryką. Natomiast ja płacę podatek tak, jakbym był indywidualnym rzemieślnikiem 'branży duchownej', co wynosi procentowo więcej. Bardzo mi pomagają w opłacaniu podatku nasze nieocenione, a nieraz przez księży niedoceniane babcie, z których każda przynosi mi od czasu do czasu po parę rubli "na podatek"'20.

Sytuacje te były niewątpliwie upokarzające i wymagały wiele wytrwałości duchowej. Apostoł Kazachstanu godził się jednak pokornie na taką niesprawiedliwość wobec własnej osoby, gdyż wiedział, że ważniejsza jest jego posługa w trudnych okolicznościach. Pokora pomagała mu ustalić, co jest ważne i priorytetowe oraz określić miejsce wyznaczone mu przez Boga. Kapłan przyjmował mężnie różne zewnętrzne zniewagi, przeciwności i upokorzenia w realizacji swego powołania. Miał głębokie poczucie godności kapłańskiej i dlatego na wzór Chrystusa służył i gotowy był oddać życie za tych, dla których się poświęcał. Mówił:

„Jesteśmy wyświęceni nie na to, byśmy się oszczędzali, lecz na to, byśmy - jak trzeba - dusze swe kładli za owce Chrystusowe" ${ }^{21}$.

\footnotetext{
${ }^{19}$ ANP 374, 32.

${ }^{20} \mathrm{~W}$. Bukowiński, Wybór wspomnień..., op.cit., s. 104.

${ }^{21}$ Ibidem, s. 110.
} 


\subsection{Ubóstwo}

Prostota, z jaką kapłan przyjmował wszelkie warunki bytowe, emanowała na innych. Wnosił w życie radość i poczucie godności. Tajemnice duchowej harmonii Bukowiński dostrzegał właśnie w swoim podejściu do dóbr, którymi mógł dysponować:

„Chodzi o branie i dawanie. Nie tak to idealnie u mnie z dawaniem wszystkiego, bo dużo jest samolubstwa i zeświecczenia, dobrze tylko, że na starość mniej dokuczają bodźce zmysłowe. Co do brania, to biorę tylko to, co konieczne dla egzystencji”22.

Życie księdza Bukowińskiego i świadectwa wielu osób pokazują jak w różnorodnych okolicznościach zachowywał on świadomość ludzkiej godności, na którą nie może mieć wpływu żadna sytuacja, także socjalna. Zachowywał i rozwijał postawę ewangelicznego ubóstwa, wykorzystując wszystkie dobra, które posiadał, do świadczenia bliźnim miłości. Odkrywając hojność Boga, sam stawał się wobec potrzebujących hojnym. Pragnienie wyrzeczenia się materialnej sfery życia dla Królestwa Bożego nie opuszczało go do końca życia, czemu dał wyraz, wracając z Polski do Kazachstanu, aby - jak mówił - i grób jego tam apostołował.

\subsection{Czystość}

Dla świadków był człowiekiem świętym. Ludzie, którzy go spotkali, na pytanie o grzechy czy niewierność kapłańską, wręcz oburzeni, odpowiadali: „To był człowiek święty”. W zgodnej opinii świadków zachowanie księdza Bukowińskiego było bez zarzutu. Był dla nich wzorem czystości i świętości, a wielu w swoich wypowiedziach łączy te określenia lub używa ich zamiennie. Jest to najlepsze potwierdzenie heroiczności tej cnoty w życiu Apostoła Kazachstanu.

\subsection{Posłuszeństwo}

Ks. Władysław był posłuszny władzom kościelnym. Choć przebywał w Kazachstanie, gdzie nie było administracji kościelnej, to jednak pozostawał w łączności z Kościołem w Polsce. Szukał także sposobu kontaktu z Prymasem Polski. Był to wyrazjego posłuszeństwa Kościołowi. Przebywając w Polsce na przełomie 1972/1973,

${ }^{22}$ Listy..., op.cit., s. 164. 
napisał list do ks. kard. Stefana Wyszyńskiego, w którym poufnie przekazał informacje o życiu Kościoła w Azji. List ten niewątpliwie można traktować jako swoisty wyraz oddania i posłuszeństwa. Czytamy w nim:

„Pozostaję z prośbą o arcypasterskie błogosławieństwo dla mnie i moich wiernych różnych narodowości, a szczególnie dla wszystkich mych podopiecznych Polaków”23.

\section{Podsumowanie}

Wspomniane wyżej przykłady z życia ks. Władysława potwierdzają realizację cnót w stopniu heroicznym. Niezależnie od warunków, w jakich żył i pracował, był wierny swojemu powołaniu dzięki przymiotom, które otrzymał i rozwijał. Przewodnią cnotą jego działalności była miłość, nigdy nie zatruta nienawiścią. Miała ona wymiar przede wszystkim miłości przebaczającej. Kościół ogłosił go błogosławionym, ażeby dać nam wzór człowieka, którego radość, pogoda ducha i wewnętrzny pokój wynikały z wiary i miłości.

\section{Literatura}

Bukowiński W., Listy, Kraków, Wydawnictwo św. Stanisława BM, 2007.

Bukowiński W., Wybór wspomnień i informacji dla moich przyjaciót, Kraków, Wydawnictwo Instytutu Teologicznego Księży Misjonarzy, 2007.

Bukowiński W., Historia nauczycielka życia, Kraków, Wydawnictwo TEZA WNT, 2007.

Nowak J., Świadek. Życie i działalność ks. Władysława Bukowińskiego, apostoła Kazachstanu, Kraków, Wydawnictwo UNUM, 2009.

Stuga Boży ks. Władysław Bukowiński (1904-1974). Materiały z sympozjum zorganizowanego w Sanktuarium Bożego Miłosierdzia w Krakowie-Łagiewnikach 23 czerwca 2007 roku w pierwszą rocznicę rozpoczęcia procesu kanonizacyjnego, red. J. Nowak, Kraków, Wydawnictwo UNUM, 2007.

${ }^{23}$ W. Bukowiński, Do moich przyjaciót..., op.cit., s. 30. 


\section{References}

Bukowiński W., Listy [Letters], Kraków, Wydawnictwo św. Stanisława BM, 2007. Bukowiński W., Wybór wspomnień i informacji dla moich przyjaciót [A Selection of Memoirs and Information for my Friends], Kraków, Wydawnictwo Instytutu Teologicznego Księży Misjonarzy, 2007.

Bukowiński W., Historia nauczycielka życia [History as a Teacher of Life], Kraków, Wydawnictwo TEZA WNT, 2007.

Nowak J., Świadek. Życie i działalność ks. Władysława Bukowińskiego, apostoła Kazachstanu [A Witness. The Life and Work of Fr. Władysław Bukowiński, the Apostle of Kazakhstan], Kraków 2009.

Stuga Boży ks. Władysław Bukowiński (1904-1974). Materiały z sympozjum zorganizowanego w Sanktuarium Bożego Miłosierdzia w Krakowie-Łagiewnikach 23 czerwca 2007 roku w pierwszą rocznicę rozpoczęcia procesu kanonizacyjnego, [The Servant of God Fr. Władysław Bukowiński, 1904-1974. Materials from the symposium of June 23, 2007, organized in the Divine Mercy Sanctuary in Kraków-Lagiewniki, on the $1^{\text {st }}$ anniversary of commencing the canonization proceedings], J. Nowak (Ed.), Kraków, Wydawnictwo UNUM, 2007. 
